\title{
Effect of various protein sources in feed on the fatty acid composition of adipose depots in lambs
}

\author{
Teodora Popova*, Marin Yossifov, Lazar Kozelov, Penka Marinova \\ Institute of Animal Science, 2232 Kostinbrod, Bulgaria
}

\section{A B S T R A C T}

\begin{abstract}
The effect of inclusion of different protein sources-sunflower meal, rapeseed meal and dry distillers' grain with solubles (DDGS) on the fatty acid profile of subcutaneous, intermuscular, omental and perirenal fat was studied in male lambs of Bulgarian Dairy Synthetic Population. The presence of sunflower meal in the diet of the lambs led to highest content $(P<0.05)$ of $C 16: 0$ in the omental fat while C18:0 displayed lowest content in the perirenal fat of the lambs fed DDGS ( $<<0.05)$. The content of $C 16: 1$ in the intermuscular adipose tissue was significantly $(P<0.05)$ affected by the dietary treatment. It was highest in the rapeseed meal fed lambs and lowest in the lambs that consumed DDGS. Significant influence of the diet on C18:1 was observed in subcutaneous and omental fat $(P<0.05)$ as its content was highest in the group fed rapeseed meal and lowest in the DDGS group. The lambs fed DDGS containing diet showed significantly increased content of $\mathrm{C} 18: 2$ and the total amount of polyunsaturated fatty acids in the subcutaneous $(\mathrm{P}<0.05)$, intermuscular and omental fat $(P<0.01)$ as well as in the perirenal fat $(P<0.001)$ and decreased content of the total saturated fatty acids in the omental and perirenal adipose tissue $(P<0.05)$. Rapeseed meal led to substantially higher content of $C 18: 3 n-3$ in the four depots when compared to the other two protein sources. These results could suggest that the inclusion of rapeseed meal and DDGS in the diet could be used to positively manipulate the lipid profile in lamb adipose tissues.
\end{abstract}

Keywords: Adipose tissue; Bulgaria; Diet composition; Fatty acids; Lambs

\section{INTRODUCTION}

Adipose tissue influences to a great extent the quality of carcass and meat in ruminant animals through its amount and composition. They both might be influenced by nutrition although the fatty acid composition of lipids in ruminants are more difficult to affect than those of monogastric animals due to the process of biohydrogenation (Voicu et al., 2008). It is known that the fat in ruminant animals is characterized by greater amount of saturated fatty acids which are not beneficial for human health and researches focus on various strategies to reduce their amount and to offer the consumers a product with a more favorable and balanced fatty acid composition. Rapeseed cultivation has increased in European countries where renewable sources of energy are becoming of great interest. Rapeseed oil has been proved to be one of the best sources for biofuel and the increasing amount of rapeseed meal has raised the interest of both nutritionists and producers (ElSolh, 2011). Rapeseed meal is considered to be a relatively good replacement of soybean meal in the diet of animals and researches have showed that feeding rapeseed to cattle or sheep reduces the content of palmitic acid (St. John et al., 1987; Lough et al., 1992), increases stearic (Solomon et al., 1991) and linoleic acids (Rule et al., 1989) in adipose tissue. Another potential alternative of feed traditional grains in the diet of lambs is the distillery by-products. Corn distillers are rich in protein, moderately rich in fat and relatively poor in fiber diet ingredients that could be fed to all classes of livestock (Hayes, 2008). In a forage and concentrate diet, DDGS can likely replace most of the protein supplement such as soybean meal and a significant amount of the grain (Schroeder, 2010). DDGS might diminish the incidence and severity of acidosis, laminitis and fatty liver caused by starch fermentation in the rumen (Schroeder, 2010; Kelzer, 2011).

The aim of this study is to examine the effect of the rapeseed meal and DDGS on the fatty acid composition of adipose depots in lambs.

\footnotetext{
${ }^{*}$ Corresponding author:

Teodora Popova, Department of Ecology and Quality of Animal Production, Institute of Animal Science, 2232 Kostinbrod, Bulgaria.

E-mail: tlpopova@yahoo.com
}

Received: 10 September 2014; 


\section{MATERIALS AND METHODS}

\section{Animals and diets}

The experiment was carried out with ram lambs of Bulgarian Dairy Synthetic Population in the Institute of Animal Science - Kostinbrod. Three groups of animals (5 lambs each) were formed according to the protein source in the diet - sunflower meal, rapeseed meal and dry distillers' corn grain with solubles (DDGS), as the first was considered control group. At the beginning of the trial, the lambs received $560 \mathrm{~g}$ of concentrate daily and its amount increased gradually until $910 \mathrm{~g}$. The composition of the diets is presented in Table 1. The animals had ad libitum access to water. The lambs were included in the experiment at the age of 60 days with mean body weight of $14.5 \mathrm{~kg}$ \pm 0.5 . The experiment lasted 90 days.

\section{Slaughter and sampling}

At the end of the experiment the animals (mean body weight of $37 \mathrm{~kg} \pm 0.7$ ) were slaughtered. Samples for fatty acid composition of the perirenal and omental fat were taken immediately after slaughter while those of the intermuscular and subcutaneous fat (over Longissimus dorsi muscle, at the $11^{\text {th }}$ rib) were taken after storing the carcasses at $4^{\circ} \mathrm{C}$ for $24 \mathrm{~h}$.

\section{Analysis of fatty acid composition}

Total lipids of the four depots were extracted according to the method of Bligh and Dyer (1959). Methyl esters of triacylglycerols, isolated by preparative TLC were obtained using $0.01 \%$ solution of sulphuric acid in dry methanol for 14h, as described by Christie (1973). The fatty acid composition of triacylglycerols was determined by GLC analysis using chromatograph C Si 200 equipped with capillary column (TR-FAME $-60 \mathrm{~m} \times 0.25 \mathrm{~mm}$ $\times 0.25 \mu \mathrm{m})$ and hydrogen as a carrier gas. The oven temperature was first set at $160^{\circ} \mathrm{C}$ for $0.2 \mathrm{~min}$, then raised until $220^{\circ} \mathrm{C}$ at a rate of $5^{\circ} \mathrm{C} / \mathrm{min}$ and hold for 5 minutes. The temperatures of the detector and injector were $230^{\circ} \mathrm{C}$. Methyl esters were identified comparing to the retention times of the standards. Fatty acids are presented

Table 1: Diet composition (\%)

\begin{tabular}{lccc}
\hline Components & \multicolumn{3}{c}{ Diets } \\
\cline { 2 - 4 } & Sunflower meal & Rapeseed meal & DDGS* \\
\hline Maize & 17.17 & 16.99 & 6.67 \\
Triticale & 17.17 & 16.99 & 16.68 \\
Sunflower meal & 26.33 & - & - \\
Rapeseed meal & - & 27.19 & - \\
DDGS & - & - & 37.58 \\
Lime & 2.35 & 1.93 & 1.43 \\
Dicalcium phosphate & 0.14 & 0.45 & 1.87 \\
Vitamin premix & 0.19 & 0.2 & 0.2 \\
Hay & 36.65 & 36.25 & 35.57 \\
\hline
\end{tabular}

${ }^{*}$ DDGS: Dry distillers grain with solubles as percentages of the total amount of the methyl esters identified (Christie, 1973).

\section{Statistical analysis}

Statistical analysis was performed using JMP, version 7 software. Data was analyzed using analysis of variance (ANOVA) to assess the influence of the protein source in the diet on the fatty acid composition of the adipose depots. The means were compared through Fisher's LSD. Differences with a level of significance below 0.05 were considered significant.

\section{RESULTS}

\section{Saturated and monounsaturated fatty acids}

Protein source in the diet did not affect significantly the saturated fatty acids in the subcutaneous and intermuscular adipose tissue (Table 2), but it had a significant influence $(\mathrm{P}<0.05)$ on the content of $\mathrm{C} 16: 0$ in the omental fat, being higher in the sunflower meal group compared to the other two. The content of the other major saturated fatty acid C18:0 was found to be significantly affected by the protein

Table 2: Content (\%) of the saturated fatty acids in the subcutaneous, intermuscular, omental and perirenal fat depots in lambs in response to the protein source in the diet (values presented as least squares means)

\begin{tabular}{|c|c|c|c|c|c|}
\hline \multirow[t]{2}{*}{ Fatty acids } & \multicolumn{3}{|c|}{ Animal groups } & \multirow[t]{2}{*}{ S.E. } & \multirow{2}{*}{$\begin{array}{l}\text { Influence of } \\
\text { the protein } \\
\text { source }\end{array}$} \\
\hline & $\begin{array}{c}\text { Sunflower } \\
\text { meal }\end{array}$ & $\begin{array}{c}\text { Rapeseed } \\
\text { meal }\end{array}$ & DDGS & & \\
\hline \multicolumn{6}{|l|}{ Subcutaneous } \\
\hline C14:0 & 3.05 & 2.56 & 3.02 & 0.48 & NS \\
\hline C15:0 & 1.17 & 0.70 & 0.67 & 0.65 & NS \\
\hline C16:0 & 24.48 & 22.89 & 22.95 & 2.38 & NS \\
\hline C17:0 & 2.44 & 1.62 & 1.42 & 0.99 & NS \\
\hline C18:0 & 12.13 & 14.58 & 13.44 & 3.07 & NS \\
\hline \multicolumn{6}{|l|}{ Intermuscular } \\
\hline C14:0 & 4.71 & 5.00 & 3.95 & 0.91 & NS \\
\hline C15:0 & 0.64 & 0.67 & 0.6 & 0.07 & NS \\
\hline C16:0 & 22.44 & 21.74 & 21.32 & 1.37 & NS \\
\hline C17:0 & 1.53 & 1.49 & 1.29 & 0.19 & NS \\
\hline C18:0 & 15.45 & 16.07 & 15.16 & 2.49 & NS \\
\hline \multicolumn{6}{|l|}{ Omental } \\
\hline C14:0 & 3.7 & 3.12 & 3.03 & 0.54 & NS \\
\hline C15:0 & 0.64 & 0.62 & 0.56 & 0.08 & NS \\
\hline C16:0 & $22.31^{a}$ & $19.37^{b}$ & $20.48^{\mathrm{ab}}$ & 1.37 & * \\
\hline C17:0 & $1.82^{\mathrm{a}}$ & $1.69^{\mathrm{ab}}$ & $1.36^{\mathrm{b}}$ & 0.24 & * \\
\hline C18:0 & 20.91 & 24.33 & 18.76 & 3.75 & NS \\
\hline \multicolumn{6}{|l|}{ Perirenal } \\
\hline C14:0 & 3.05 & 2.32 & 2.68 & 0.56 & NS \\
\hline C15:0 & 0.51 & 0.49 & 0.48 & 0.08 & NS \\
\hline C16:0 & 18.26 & 16.77 & 17.83 & 1.34 & NS \\
\hline C17:0 & $1.79^{a}$ & $1.63^{a}$ & $1.34^{\mathrm{b}}$ & 0.15 & $* *$ \\
\hline C18:0 & $26.38^{\mathrm{ab}}$ & $28.07^{a}$ & $22.16^{b}$ & 3.29 & * \\
\hline
\end{tabular}


source but only in the perirenal fat $(\mathrm{P}<0.05)$, as its levels were largest in the group fed rapeseed.

The protein source influenced significantly the content of $\mathrm{C} 17: 0$ in omental $(\mathrm{P}<0.05)$ and perirenal $(\mathrm{P}<0.01)$ fat, as in both depots it displayed the highest amounts in the sunflower meal group and lowest in the groups that received DDGS. The total amount of saturated fatty acids (Table 5) was significantly $(\mathrm{P}<0.05)$ affected by the diet in both omental and perirenal adipose tissue, showing reduced content in the group fed DDGS.

Influence of the diet on individual monounsaturated fatty acids was observed in all four depots (Table 3).

Palmitoleic fatty acid (C16:1) was influenced by the protein source in the diet $(\mathrm{P}<0.05)$ in the intermuscular adipose tissue and its content was highest in the rapeseed meal fed lambs and lowest in the lambs consumed DDGS. Significant $(\mathrm{P}<0.05)$ influence of the diet was observed on C18:1 of the subcutaneous and omental fat where its content was higher in the group fed rapeseed meal and lower in the DDGS group. Differences in the dietary treatments influenced significantly the content of trans $\mathrm{C} 18: 1$ in the intermuscular $(\mathrm{P}<0.05)$, omental and perirenal $(\mathrm{P}<0.01)$ adipose depots, its amount being the highest in the DDGS group.

Stearoyl-CoA desaturase (SCD) and elongase activities as presented in Table 5 have been calculated after

\begin{tabular}{|c|c|c|c|c|c|}
\hline \multirow[t]{2}{*}{ Fatty acids } & \multicolumn{3}{|c|}{ Animal groups } & \multirow[t]{2}{*}{ S.E. } & \multirow{2}{*}{$\begin{array}{l}\text { Influence of } \\
\text { the protein } \\
\text { source }\end{array}$} \\
\hline & $\begin{array}{c}\text { Sunflower } \\
\text { meal }\end{array}$ & $\begin{array}{l}\text { Rapeseed } \\
\text { meal }\end{array}$ & DDGS & & \\
\hline \multicolumn{6}{|l|}{ Subcutaneous } \\
\hline C16:1 & 2.37 & 1.78 & 1.80 & 0.51 & NS \\
\hline trans C18:1 & 1.45 & 0.93 & 5.56 & 3.49 & NS \\
\hline C18:1 & $48.14^{\mathrm{a}}$ & $50.36^{a b}$ & $44.28^{a}$ & 3.52 & * \\
\hline \multicolumn{6}{|l|}{ Intermuscular } \\
\hline C16:1 & $2.08^{\mathrm{ab}}$ & $2.25^{a}$ & $1.37^{b}$ & 0.50 & * \\
\hline trans C18:1 & $0.98^{a}$ & $0.71^{a}$ & $5.21^{\mathrm{b}}$ & 2.44 & * \\
\hline C18:1 & 45.81 & 45.59 & 42.92 & 2.34 & NS \\
\hline \multicolumn{6}{|l|}{ Omental } \\
\hline C16:1 & 1.44 & 1.12 & 0.90 & 0.50 & NS \\
\hline trans C18:1 & $1.68^{\mathrm{a}}$ & $1.23^{\mathrm{a}}$ & $8.49^{b}$ & 2.69 & $* *$ \\
\hline C18:1 & $40.94^{\mathrm{ab}}$ & $41.93^{\mathrm{a}}$ & $38.19^{b}$ & 2.22 & * \\
\hline \multicolumn{6}{|l|}{ Perirenal } \\
\hline C16:1 & 1.15 & 0.62 & 0.82 & 0.44 & NS \\
\hline trans $\mathrm{C} 18: 1$ & $1.78^{a}$ & $1.24^{\mathrm{a}}$ & $5.17^{b}$ & 1.22 & $\star \star$ \\
\hline C18:1 & 40.14 & 42.21 & 40.93 & 1.80 & NS \\
\hline
\end{tabular}

${ }^{*} P<0.05$; ${ }^{* *} P<0.01$. Values connected with different letters are significantly different $(P<0.05)$. S.E: Standard error, DDGS: Dry distillers grain with solubles, NS: Non significant determination of the content of the respective saturated (C16:0 and C18:0) and monounsaturated fatty acids (C16:1 and C18:1). In all four depots SCD was not affected by the diet whereas the elongase activity differed significantly $(\mathrm{P}<0.001)$ among groups in the perirenal fat corresponding to the changes observed in the content of C18:0.

\section{Polyunsaturated fatty acids}

The different protein sources of the diet influenced significantly the contents of C18:2 and C18:3n-3 in the four adipose depots (Table 4). In all depots the C18:2 displayed approximately 1.5 times higher content in the group fed DDGS, while C18:3n-3 had highest content in the rapeseed meal group. Dietary treatment affected significantly the content of $\mathrm{C} 18: 3 \mathrm{n}-6$ in intermuscular $(\mathrm{P}<0.01)$ and omental fat $(\mathrm{P}<0.001)$ as the group fed DDGS had lowest amount of this fatty acid. Significant influence $(\mathrm{P}<0.05)$ of the dietary protein source on the amount of total CLA was observed in the perirenal fat where highest content was quantified for the lambs that consumed rapeseed meal and the lowest in the group fed DDGS.

The total amount of the polyunsaturated fatty acids was significantly affected by the dietary treatment in the subcutaneous $(\mathrm{P}<0.05)$, intermuscular and omental $(\mathrm{P}<0.01)$ as well as perirenal $(\mathrm{P}<0.001)$ adipose depots

Table 4: Content (\%) of the polyunsaturated fatty acids in the subcutaneous, intermuscular, omental and perirenal fat depots in lambs in response to the protein source in the diet (values presented as least squares means)

\begin{tabular}{|c|c|c|c|c|c|}
\hline \multirow[t]{2}{*}{ Fatty acids } & \multicolumn{3}{|c|}{ Animal groups } & \multirow[t]{2}{*}{ S.E } & \multirow{2}{*}{$\begin{array}{l}\text { Influence of } \\
\text { the protein } \\
\text { source }\end{array}$} \\
\hline & $\begin{array}{c}\text { Sunflower } \\
\text { meal }\end{array}$ & $\begin{array}{c}\text { Rapeseed } \\
\text { meal }\end{array}$ & DDGS & & \\
\hline \multicolumn{6}{|l|}{ Subcutaneous } \\
\hline C18:2 & $3.62^{\mathrm{a}}$ & $3.28^{a}$ & $5.64^{\mathrm{b}}$ & 1.27 & * \\
\hline C18:3n-6 & 0.23 & 0.2 & 0.23 & 0.12 & NS \\
\hline C18:3n-3 & $0.23^{a}$ & $0.38^{b}$ & $0.32^{\mathrm{ab}}$ & 0.08 & * \\
\hline Total CLA & 0.61 & 0.67 & 0.60 & 0.17 & NS \\
\hline \multicolumn{6}{|l|}{ Intermuscular } \\
\hline C18:2 & $4.76^{a}$ & $4.57^{a}$ & $6.50^{\mathrm{b}}$ & 0.74 & ** \\
\hline C18:3n-6 & $0.31^{\mathrm{a}}$ & $0.29^{a}$ & $0.24^{b}$ & 0.03 & $* *$ \\
\hline C18:3n-3 & $0.47^{\mathrm{a}}$ & $0.69^{b}$ & $0.53^{a}$ & 0.09 & $* *$ \\
\hline Total CLA & 0.76 & 0.87 & 0.85 & 0.10 & NS \\
\hline \multicolumn{6}{|l|}{ Omental } \\
\hline C18:2 & $5.28^{a}$ & $4.96^{a}$ & $6.97^{b}$ & 0.86 & ** \\
\hline C18:3n-6 & $0.26^{a}$ & $0,28^{a}$ & $0.19^{b}$ & 0.02 & $* * *$ \\
\hline C18:3n-3 & $0.33^{a}$ & $0.57^{b}$ & $0.37^{a}$ & 0.06 & $* * *$ \\
\hline Total CLA & 0.62 & 0.74 & 0.64 & 0.10 & NS \\
\hline \multicolumn{6}{|l|}{ Perirenal } \\
\hline C18:2 & $5.67^{a}$ & $5.11^{\mathrm{a}}$ & $7.30^{b}$ & 0.60 & $* * *$ \\
\hline C18:3n-6 & 0.25 & 0.20 & 0.18 & 0.07 & NS \\
\hline C18:3n-3 & $0.28^{a}$ & $0.51^{\mathrm{b}}$ & $0.37^{c}$ & 0.05 & $* * *$ \\
\hline Total CLA & $0.69^{\mathrm{ab}}$ & $0.77^{\mathrm{a}}$ & $0.66^{b}$ & 0.06 & * \\
\hline
\end{tabular}

${ }^{*} \mathrm{P}<0.05 ;{ }^{* *} \mathrm{P}<0.01,{ }^{* * *} \mathrm{P}<0.001$. Values connected with different letters are significantly different $(P<0.05)$. S.E: Standard error, CLA: Conjugated linoleic acid, DDGS: Dry distillers grain with solubles, NS: Non significant 
Table 5: Total amounts (\%) of the saturated, mono- and polyunsaturated fatty acids, and indices of atherogenicity, stearoyl CoA desaturase and elongase activities in the four depots in lambs in response to the protein source in the diet (values presented as least squares means)

\begin{tabular}{|c|c|c|c|c|c|}
\hline \multirow[t]{2}{*}{ Fatty acids } & \multicolumn{3}{|c|}{ Animal groups } & \multirow{2}{*}{ S.E. } & \multirow{2}{*}{$\begin{array}{l}\text { Influence of } \\
\text { the protein } \\
\text { source }\end{array}$} \\
\hline & $\begin{array}{c}\text { Sunflower } \\
\text { meal }\end{array}$ & $\begin{array}{c}\text { Rapeseed } \\
\text { meal }\end{array}$ & DDGS & & \\
\hline \multicolumn{6}{|l|}{ Subcutaneous } \\
\hline SFA & 42.29 & 42.36 & 41.53 & 2.99 & NS \\
\hline MUFA & 51.97 & 53.08 & 51.64 & 1.97 & NS \\
\hline PUFA & $4.72^{\mathrm{a}}$ & $4.54^{\mathrm{a}}$ & $6.81^{\mathrm{b}}$ & 1.34 & * \\
\hline Atherogenicity & 0.65 & 0.57 & 0.60 & 0.09 & NS \\
\hline Stearoyl CoA Al & 0.58 & 0.38 & 0.55 & 2.73 & NS \\
\hline Elongase Al & 0.50 & 0.64 & 0.60 & 0.17 & NS \\
\hline \multicolumn{6}{|l|}{ Intermuscular } \\
\hline SFA & 44.79 & 44.99 & 42.34 & 2.19 & NS \\
\hline MUFA & 48.88 & 48.56 & 49.52 & 2.00 & NS \\
\hline PUFA & $6.31^{a}$ & $6.34^{a}$ & $8.13^{b}$ & 0.68 & $* *$ \\
\hline Atherogenicity & 0.74 & 0.76 & 0.64 & 0.09 & NS \\
\hline Stearoyl CoA Al & 0.56 & 0.56 & 0.56 & 2.13 & NS \\
\hline Elongase Al & 0.69 & 0.74 & 0.71 & 0.14 & NS \\
\hline \multicolumn{6}{|l|}{ Omental } \\
\hline SFA & $49.41^{a}$ & $49.15^{a}$ & $44.20^{b}$ & 3.18 & * \\
\hline MUFA & 44.07 & 44.28 & 47.59 & 2.93 & NS \\
\hline PUFA & $6.51^{\mathrm{a}}$ & $6.56^{a}$ & $8.19^{b}$ & 0.82 & $\star *$ \\
\hline Atherogenicity & $0.73^{a}$ & $0.62^{\mathrm{ab}}$ & $0.58^{b}$ & 0.07 & * \\
\hline Stearoyl CoA Al & 0.49 & 0.50 & 0.50 & 2.75 & NS \\
\hline Elongase Al & 0.94 & 1.26 & 0.93 & 0.24 & NS \\
\hline \multicolumn{6}{|l|}{ Perirenal } \\
\hline SFA & $50.02^{a}$ & $49.30^{a}$ & $44.52^{b}$ & 2.63 & * \\
\hline MUFA & 43.07 & 44.09 & 46.94 & 2.50 & NS \\
\hline PUFA & $6.90^{\mathrm{a}}$ & $6.60^{\mathrm{a}}$ & $8.52^{\mathrm{b}}$ & 0.60 & $* * *$ \\
\hline Atherogenicity & 0.61 & 0.51 & 0.51 & 0.07 & NS \\
\hline Stearoyl CoA Al & 0.48 & 0.49 & 0.47 & 5.32 & NS \\
\hline Elongase Al & $1.46^{a}$ & $1.68^{a}$ & $0.54^{b}$ & 0.23 & $* * *$ \\
\hline
\end{tabular}

${ }^{*} P<0.05 ;{ }^{* *} P<0.01 ;{ }^{* * *} P<0.001$. Values connected with different letters are significantly different $(P<0.05)$. Atherogenic index $=((4 \times C 14: 0)+C 16: 0)) /($ MUFA+PUFA $)$. activity index $=(C 16: 1+C 18: 1) /$ $(C 16: 0+C 16: 1+C 18: 0+C 18: 1)$. Elongase activity index $=C 18: 0 / C 16: 0$, DDGS: Dry distillers grain with solubles, NS: Non significant, S.E: Standard error, SFA: Total saturated fatty acids, MUFA: Total monounsaturated fatty acids, PUFA: Total polyunsaturated fatty acids, Al: Activity index, SCD: Stearoyl CoA desaturase

(Table 5). Although significant change in the content of PUFA in response to the different protein sources in the diet was observed in the adipose depots, atherogenic index differed among groups only in the omental fat $(\mathrm{P}<0.05)$.

\section{DISCUSSION}

\section{Saturated and monounsaturated fatty acids}

The four depots (subcutaneous, intermuscular, omental and perirenal fats) analyzed in this work differ in their physiological functions as well as chemical properties and hence in their fatty acid composition which might be influenced by various nutritional factors. Protein source in the diet affected the content of the major saturated fatty acids C16:0 and C18:0 in the omental and perirenal fat respectively. C16:0 was higher in the sunflower meal fed group. The contents of C18:0 was highest in the internal fat depots of the lambs fed rapeseed meal and similar trend was observed for the subcutaneous and intermuscular fat. Our results are in line with Solomon et al. (1991) who reported an increase in the content of C18:0 of subcutaneous adipose tissue in growing ram lambs fed whole rapeseed-soybean meal-supplemented diet while Rule et al. (1989) also observed increased stearic acid content of subcutaneous adipose tissue of steers fed canola seed supplemented diet.

Besides C16:0 and C18:0, the dietary treatment affected the contents of $\mathrm{C} 17: 0$, which was highest in the group fed sunflower meal. Although no significantly different, the contents of C15:0 followed the trends of C17:0. An increase in the odd-chain fatty acid contents might be due to some alteration in ruminal fermentation products. Augmented odd chain fatty acid concentration has been attributed to the substitution of propionate for acetate in de novo fatty acid synthesis (Marmer et al., 1985; Gilka et al., 1989).

The highest content of the monounsaturated fatty acids belongs to C18:1 which is one of the three major fatty acids in the tissues of the animals (including C16:0 and C18:0). C18:1 is the most abundant fatty acid which is in agreement with other studies (Kott et al., 2003; Boles et al., 2005; Juarez et al., 2008). Significant influence of the dietary treatment on C18:1 was observed in subcutaneous and omental fat showing highest content in the group fed rapeseed meal and lowest in the DDGS group. The greater content of C18:1 in rapeseed meal group might indicate partial biohydrogenation protection of this fatty acid (Or-Rashid et al., 2008). The other two monounsaturated fatty acids in the lamb adipose depots included C16:1 and transC18:1. The latter was affected by the diet in the intermuscular, omental and perirenal fat and displayed highest amounts in the DDGS group. These results are in agreement with those of Whitney and Braden, 2010 in lambs. Contrary to us, Dugan et al. (2010) did not find any significant changes in the amount of total saturated and monounsaturated fatty acids in the adipose tissue in beef.

In growing lambs the adipose tissue is the main site for fatty acid synthesis de novo with C16:0 as a major product which can be further elongated to C18:0 and desaturated to $\mathrm{C} 18: 1$ by the stearoyl-CoA desaturase. Stearoyl-CoA desaturase activity was not significantly influenced by the diet and there is no evident connection between the values of the desaturase index as described by Malau-Aduli et al. (1998) and the contents of total monounsaturated fatty 
acids. In their study Chang et al. (1992) reported higher desaturase activity in steers fed high oleate sunflower seed supplemented diet. This is in contrast with our study where the rapeseed meal diet had the highest content of C18:1. On the other hand the group fed DDGS displayed high content of trans $\mathrm{C} 18: 1$ compared to the other two groups. In sheep the stearoyl-CoA desaturase is produced by a gene whose activity varies in the different depots and does not depend by the general fat synthesis (Ward et al., 1998), while Taniguchi et al. (2004) showed that the level of expression of SCD mRNA is related to the amount of monounsaturated fatty acids in ruminants and described single nucleotide polymorphism, which contributed to a higher MUFA percentage.

Elongase activity index differed among the individual depots but the internal fat displayed much higher elongase activity when compared to the intermuscular and subcutaneous adipose tissues. Elongase activity was also affected by the diet components in the perirenal fat where the group fed DDGS displayed the lowest values.

\section{Polyunsaturated fatty acids}

The various protein sources in the diet influenced significantly the contents of C18:2 in all depots as it was higher in the group fed DDGS. On the other hand C18:3n-6 showed lower amounts in the DDGS group. Gill et al. (2008) reported increased content of n-6 polyunsaturated fatty acids when feeding cattle with DDGS which is in line with our results for C18:2 and opposite to the results of our study for the contents of C18:3n-6. Other studies report increased content of C18:2 in the brisket fat in beef and no change in the content of C18:3n-3 (Dugan et al., 2010).

Significant influence of the dietary protein source on the amount of total CLA was determined in the perirenal fat where the highest content was quantified for the lambs that consumed rapeseed meal and the lowest in the group fed DDGS. According to Griinari et al. (2000) the cis-9, trans-11 CLA isomer originates exclusively through the biohydrogenation pathway which can be reduced by increasing ruminal acidity (Harfoot and Hazelwood, 1997). Kim et al. (2007) stated that the greater C18:2 in lamb resulted from greater C18:2 escaping a more acidic ruminal environment. In addition the biohydrogenation proceeds to a greater extent as non-digestible fibers concentration increases (Sackman et al., 2003), which is related to cellulolytic microbes being the primary microbes involved in biohydrogenation. Depenbusch et al. (2009) reported that feeding DDGS may favor cellulolytic bacteria in the rumen. Even though nondigestible fibers did not change in the diet, ruminal $\mathrm{pH}$ may have decreased, resulting in lower extent of biohydrogenation. DDGS small particle size may reduce its effective fiber and feeding DDG with solubles has reduced ruminal pH (Schingoethe, 2006; May, 2007; Uwituze, 2008).

The total amount of the polyunsaturated fatty acids was significantly affected by the dietary treatment of the lambs in all four depots and the changes corresponded to those of the C18:2.

Atherogenic index has been calculated according to Ulbricht and Southgate (1991). The higher the atherogenic index of the fats, the more detrimental they are for the human health. The values of atherogenic index that we reported in the fats are similar to those of Kaszor et al. (2010) in adipose tissue in lambs. Although we observed significant influence of the diet on the content of polyunsaturated fatty acids in all four examined depots, the atherogenic index was affected only in the omental fat, where its values were lowest in the group fed DDGS and highest in the sunflower meal fed group.

\section{CONCLUSIONS}

The results of this study showed that the fatty acid composition of the adipose tissue in lambs could be manipulated by the inclusion of various protein sources in the diet and the lipid profile varied in a depot specific way. The content of total saturated fatty acids was influenced significantly by the diet in the internal fat depots as the inclusion of DDGS lowered their amount. Besides DDGS in the diet increased significantly the content of total polyunsaturated fatty acids in all four depots mainly at the expense of C18:2 while rapeseed meal led to significantly higher content of $\mathrm{C} 18: 3 \mathrm{n}-3$. This could suggest that the inclusion of these two protein sources could serve to manipulate the profile of lamb fatty acids in a positive way.

\section{Author contributions}

T. P. performed the fatty acid analysis and the statistical evaluation of the data. M. Y. and L. K. conceived and designed the experiment. M. Y. conducted the experiment. T. P. wrote the manuscript. P. M. was involved in the manuscript revision. L. K. and P. M. provided general supervision of the work.

\section{REFERENCES}

Bligh, E. G. and W. Y. Dyer. 1959. A rapid method of total lipid extraction and purification. Can. J. Biochem. Physiol. 37: 911-917.

Boles, J. A., R. W. Kott, P. G. Hatfield, J. W. Bergman and C. R. Flynn. 2005. Supplemental safflower oil affects the fatty acid profile, including conjugated linoleic acid of lamb. J. Anim. Sci. 83: 2175-2181.

Chang, J. H. P., D. K. Lunt and S. B. Smith. 1992. Fatty acid composition and fatty elongase and stearoyl-CoA desaturase 
activities in tissues of steers fed high oleate sun-flower seed. J. Nutr. 122: 2074-2080.

Christie, W. W. 1973. Lipid Analysis. Pergamon Press, Oxford.

Depenbusch, B. E., C. M. Coleman, J. J. Higgins and J. S. Drouillard. 2009. Effects of increasing levels of dried corn distillers grains with solubles on growth performance, carcass characteristics, and meat quality of yearling heifers. J. Anim. Sci. 87: 2653-2663.

Dugan, M. E. R., N. Aldai, J. K. G. Kramer, D. J. Gibb, M. Juárez and T. A. McAllister. 2010. Feeding wheat dried distillers grains with solubles improves beef trans and conjugated linoleic acid profiles. J. Anim. Sci. 88: 1842-1847.

EISolh, N. 2011. The Manufacture of Biodiesel from the Used Vegetable Oil. Master's Thesis. Kassel and Cairo Universities.

Harfoot, C. G. and G. P. Hazelwood. 1997. Lipid metabolism in the rumen. In: P. N. Hobson and C. S. Stewart, editors. The Rumen Microbial Ecosystem. Blackie Academic and Professional, London, UK. pp382-426.

Hayes, D. J. 2008. Introduction. In: B. A. Babcock, D. J. Hayes and J. D. Lawrence, editors. Using distillers' grains in the US and international livestock and poultry industries. MATRIC, lowa State University.

JMP, V. 7. SAS Institute Inc. 2007, Cary, NC.

Juarez, M., A. Jorcada, M. J. Alcalde, M. Valera, M. A. Mullen and A. Molina. 2008. Estimation of factors influencing fatty acid profiles in light lambs. Meat Sci. 79: 203-210.

Gilka, J., P. Jelinek, B. Jankova, P. Krejci and J. Habrda. 1989. Amino acid composition of meat, fatty acid composition of fat and content of some chemical elements in the tissues of male lambs fed monensin or lasalocid. Meat Sci. 25: 273-280.

Gill, R. K., D. L. van Overbeke, B. Depenbusch, J. S. Drouillard and A. DiCostanzo. 2008. Impact of beef cattle diets containing corn or sorghum distiller's grains on beef color, fatty acid profiles, and sensory attributes. J. Anim. Sci. 86: 923-935.

Griinari, J. M., B. A. Corl, S. H. Lacy, P. Y. Chouinard, K. V. V. Nurmela and D. E. Bauman. 2000. Conjugated linoleic acid is synthesized endogenously in lactating dairy cows by $\Delta 9$-desaturase. J. Nutr. 130: 2285-2291.

Kazcor, U., B. Borys and H. Pustkowyak. 2010. Effect of intensive fattening of lambs with forages on the fatty acid profile of intramuscular and subcutaneous fat. Czech J. Anim. Sci. 55: 408-419.

Kelzer, M., J. M. Popowski, S. Bird, R. B. Cox, G. I. Crawford and A. DiCostanzo. 2011. Effects of including low fat, high protein dried distillers grains in finishing diets on feedlot performance and carcass characteristics of beef steers. University of Minnesota Beef Report Publication, BR-1104.

Kim, S. C., A. T. Adesogan, L. Badinga and C. R. Staples. 2007. Effects of dietary n-6: n-3 fatty acid ratio on feed intake, digestibility, and fatty acid profiles of the ruminal contents, liver, and muscle of growing lambs. J. Anim. Sci. 85: 706-716.

Kott, R. W., P. G. Hatfield, J. W. Bergman, C. R. Flynn, H. van Wagoner and J. A. Boles. 2003. Feedlot performance, carcass composition, and muscle and fat CLA concentrations of lambs fed diets supplemented with safflower seeds. Small Rum. Res. 49: 11-17.

Lough, D. S., M. B. Solomon, T. S. Rumsey, T. H. Elsasser, L. L. Slyter, S. Kahl and G. P. Lynch. 1992. Content and fatty acid composition of carcass tissues of growing ram lambs. Effects of dietary canola seed and soy lecithin in high-forage diets on cholesterol. J. Anim. Sci. 70: 1153-1158.
Malau-Aduli, A. E. O., B. D. Siebert, C. D. K. Bottema and S. Pitchford. 1998. Breed composition of the fatty acid composition of muscle phospholipids in Jersey and Limousin cattle. J. Anim. Sci. 76: 766-773.

Marmer, W. N., J. R. Maxwell and D. G. Wagner. 1985. Effects of dietary monensin on bovine fatty acid profiles. J. Agric. Food Chem. 33: 67-70.

May, L. M. 2007. The effects of grain processing method, wet and dry distiller's grains with solubles and roughage level on performance and carcass characteristics of finishing cattle Master's Thesis. Kansas State University, Manhattan.

Or-Rashid, M. M., J. K. G. Kramer, M. A. Wood and B. W. McBride. 2008. Supplemental algal meal alters the ruminal trans-18: 1 fatty acid and conjugated linoleic acid composition in cattle. J. Anim. Sci. 86: 187-196.

Rule, D. C., W. H. Wu, J. R. Busboom, F. C. Hinds and C. J. Kercher. 1989. Dietary canola seeds alters the fatty acid composition of bovine subcutaneous adipose tissue. Nutr. Rep. Int. 39: 781.

Sackman, J. R., S. K. Duckett, M. H. Gillis, C. E. Realini, A. H. Parks and R. B. Eggelston. 2003. Effects of forage and sunflower oil levels on ruminal biohydrogenation of fatty acids and conjugated linoleic acid formation in beef steers fed finishing diets. J. Anim. Sci. 81: 3174-3181.

Schingoethe, D. J. 2006. Feeding ethanol byproducts to dairy and beefcattle. Proc. California Animal Nutrition Conference, Fresno, California. pp49-63.

Schroeder, J. W. 2010. Distillers grains for dairy cattle. North Dakota Extension Service, AS-1241.

Solomon, M. B., G. P. Lynch, E. Paroczay and S. Norton. 1991. Influence of rapeseed meal, whole rapeseed, and soybean meal on fatty acid composition and cholesterol content of muscle and adipose tissue from ram lambs. J. Anim. Sci. 69: 4055-4061.

St. John, L. C., C. R. Young, D. A. Knabe, L. D. Thompson, G. T. Schelling, S. M. Grundy and S. B. Smith. 1987. Fatty acid profiles and sensory and carcass traits of tissues from steers and swine fed an elevated monounsaturated fat diet. J. Anim. Sci. 64: 1441-1447.

Taniguchi, M., H. Mannen, K. Oyama, Y. Shimakura, A. Oka, H. Watanabe, T. Kojima, A. Komatu, G. S. Harper and S. Tsuji. 2004. Differences in stearoyl-CoA desaturase mRNA levels between Japanese Black and Holstein cattle. Livest. Prod. Sci. 87: $215-220$.

Ulbricht, T. L. V. and D. A. T. Southgate. 1991. Coronary heart disease - Seven dietary factors. Lancet. 338: 985-992.

Uwituze, S. 2008. The effects of feeding dry distiller's grains with solubles on ruminal metabolism, growth performance, and carcass traits of feedlot cattle. Master's Thesis. Kansas State University, Manhattan.

Voicu, D., V. Habean, I. Voicu and M. Habeanu. 2008. Effect of using high oleaginous (full-fat soy, rapeseeds) diets on cattle meat production and quality. Arch. Zootech. 11: 45-53.

Ward, R. J., M. T. Travers, S. E. Richards, R. G. Vernon, P. J. Buttery and M. C. Barber. 1998. Stearoyl - CoA desaturase mRNA is transcribed from a single gene in ovine genome. Biochim. Biophys. Acta. 1391: 145-156.

Whitney, T. R. and K. W. Braden. 2010. Substituting corn dried distillers grains for cottonseed meal in lamb finishing diets: Carcass characteristics, meat fatty acid profiles, and sensory panel traits. Sheep Goat. 25: 49-56. 